\title{
ПІСЛЯДИПЛОМНА ОСВІТА МЕДИЧНИХ СЕСТЕР: АНАЛІЗ ФОРМ І МЕТОДІВ НАВЧАННЯ В УКРАЇНI
}

\author{
Н. С. Ружило ${ }^{1}$, Н. О. Теренда ${ }^{2}$ \\ ${ }^{1}$ Комунальне некомерційне підприємство «Обласна клінічна лікарня \\ Івано-Франківської обласної ради" \\ ${ }^{2}$ Тернопільський національний медичний університет \\ імені І. Я. Горбачевського МОЗ Украӥни
}

У статті проаналізовано форми освіти, на основі яких може здійснюватися післядипломна освіта медичних сестер. Зростання частки неформальноїосвіти сприятиме більшдинамічномута ефективномунабуттю нових компетентностей у діяльності медичних сестер, підвищуватиме їхній рівень конкурентоздатності на ринку праці, покращить ефективність надання медичної допомоги.

\section{POSTGRADUATE EDUCATION OF NURSES: ANALYSIS OF FORMS AND METHODS OF EDUCATION IN UKRAINE}

\author{
N. S. Ruzhylo ${ }^{1}$, N. O. Terenda ${ }^{2}$ \\ ${ }^{1}$ Ivano-Frankivsk Regional Clinical Hospital \\ ${ }^{2}$ I. Horbachevsky Ternopil National Medical University
}

\begin{abstract}
The article analyzes the forms of education on the basis of which nursing postgraduate education can be carried out. Increasing the share of non-formal education will facilitate the more dynamic and effective acquisition of new competencies in the activities of nurses, increase their level of competitiveness in the labor market, and improve the efficiency of health care delivery.
\end{abstract}

Вступ. Однією з провідних ідей кінця XX - початку XXI ст. стала концепція безперервної освіти, в основі якої лежить твердження про необхідність навчання впродовж життя в сучасному технізованому та інформатизованому світі. Сучасна наука розвивається настільки швидко, що часто професійні знання, здобуті людиною, вже за кілька років стають застарілими та потребують оновлення. Більше того, сучасне життя вимагає від людей мобільності, здатності до змін, у тому числі й у професійній діяльності.

Основна частина. Закон України «Про освіту» гарантує отримання медичними сестрами освіти впродовж життя, «спрямованої на реалізацію права кожної повнолітньої особи на безперервне навчання з урахуванням її особистісних потреб, пріоритетів суспільного розвитку та потреб економіки» (ст. 18, п. 1) [1]. Держава визнає такі форми освіти: формальну, неформальну, інформальну. Основними складовими такої освіти $\epsilon$ :

(ㄱ Н. С. Ружило, Н. О. Теренда, 2020
- післядипломна освіта впродовж трудової кар'єри, яка «передбачає набуття нових та вдосконалення раніше набутих компетентностей на основі здобутої вищої, професійної (професійно-технічної) або фахової перед вищої освіти та практичного досвіду» (ст. 18, п. 5);

- професійне навчання працівників;

- курси перепідготовки та/або підвищення кваліфікації;

- безперервний професійний розвиток;

- будь-які інші складові, що передбачені законодавством, запропоновані суб'єктом освітньої діяльності або самостійно визначені особою.

Післядипломна освіта включає (ст. 18, п. 6):

- спеціалізацію - профільну спеціалізовану підготовку з метою набуття особою здатності виконувати завдання та обов'язки, що мають особливості в межах спеціальності;

- перепідготовку - освіту дорослих, спрямовану на професійне навчання з метою оволодіння іншою (іншими) професією (професіями); 
- підвищення кваліфікації - набуття особою нових та/або вдосконалення раніше набутих компетентностей у межах професійної діяльності або галузі знань;

- стажування - набуття особою практичного досвіду виконання завдань та обов'язків у певній професійній діяльності або галузі знань;

- курси підвищення кваліфікації проводять для набуття здобувачем освіти нових компетентностей у межах професійної діяльності або галузі знань;

- безперервний професійний розвиток - це безперервний процес навчання та вдосконалення професійних компетентностей фахівців після здобуття вищої та/або післядипломної освіти, що дає змогу фахівцю підтримувати або покращувати стандарти професійної діяльності й триває впродовж усього періоду його професійної діяльності.

Міністерством охорони здоров'я України від 07.09.1993 р. затверджено наказ № 198 «Про підвищення кваліфікації молодших спеціалістів з медичною та фармацевтичною освітою», яким фактично регламентовано здобуття післядипломної освіти молодшими спеціалістами з медичною та фармацевтичною освітою (медичними сестрами, фельдшерами, акушерками, лаборантами та фармацевтами).У 2007 р. мОз України затверджено наказ № 742 «Про атестацію молодших спеціалістів з медичною освітою». На сьогодні набрала чинності Постанова Кабінету Міністрів України від 28 березня 2018 р. № 302 «Про затвердження Положення про систему безперервного професійного розвитку фахівців у сфері охорони здоров'я».

Згідно з Положенням, медичні працівники зобов'язані підвищувати свою професійну компетентність впродовж всього періоду діяльності у сфері медицини після закінчення інтернатури. Періодично провадять атестацію медичних працівників.

Упродовж професійного розвитку кожен медичний працівник формує особисте освітнє портфоліо - сукупність задокументованих відомостей щодо персональних досягнень, проходження підвищення кваліфікації, неформальної та інформальної освіти.

Результати саморозвитку враховують під час атестації для присвоєння або підтвердження кваліфікаційної категорії або кваліфікації працівника чи продовження дії ліцензії на провадження господарської діяльності з медичної практики.

Інформальна освіта по суті $\epsilon$ різновидом неформальної освіти: участь у медичних конференціях, семінарах, тренінгах, майстер-класах тощо.
За проходження безперервного професійного розвитку нараховують бали, що підлягають обліку, які веде сам медичний працівник (шляхом особистого освітнього портфоліо) та роботодавець. За допомогою балів формують особисту освітню траєкторію медика.

Безперервний професійний розвиток включає формальну, неформальну та інформальну освіту.

В Європі перші формати неформальної освіти в сучасному розумінні з'явилися у Швеції. Проблеми із розуміння важливості та ефективності неформального навчання призвели до декларування в 1996 р. теми «освіти впродовж всього життя» на рівні Організації з безпеки і співробітництва в Європі (ОБСЄ) [2]. Найбільш широко всі форми безперервної освіти запроваджують в освітянській галузі.

У «Меморандумі безперервної освіти Європейського Союзу» (Лісабон, березень 2000 р.) визначено три види освітньої діяльності: формальна освіта, результатом якої є отримання загальновизнаного диплома чи атестата; неформальна освіта, що, зазвичай, не передбачає отримання документа, здійснюється в освітніх закладах або громадських організаціях, клубах, гуртках, а також під час індивідуальних занять з репетитором або тренером; інформальне навчання - індивідуальна пізнавальна діяльність, що супроводжує щоденне життя і не обов'язково має цілеспрямований характер [3].

Рада Європи завжди сприяла визнанню неформальної освіти. Варто згадати Рекомендацію (2003) про сприяння та визнання неформальної освіти молоді (цей документ рекомендує створення Європейського портфоліо для працюючих у позашкільних рамках молодіжних лідерів та молодіжних працівників); Симпозіум з неформального навчання (Страсбург, 13-15 жовтня 2000 р.) та спільну конференцію Ради Європи та Ресурсного центру SALTO «Мости для визнання» (м. Льовен, 19-23 січня 2005 р.), а також розробку Європейського портфоліо для молодіжних лідерів та молодіжних працівників із неформального навчання (2007).

Для визнання неформальної освіти необхідно враховувати два критерії: з одного боку, набуті в рамках освіти ключові компетенції, з іншого боку, соціальне визнання, спрямоване на визначення статусу і самооцінку індивідів, які беруть активну участь у добровільній діяльності [4-6].

Згідно з стандартами ЮНЕСКО, інформальна освіта - форма освіти, що $є$ цілеспрямованою або ре- 
тельно спланованою, але не інституціоналізованою, тобто менше організована і структурована, ніж формальна і неформальна освіта. Інформальна освіта може включати навчальну діяльність в родині, на робочому місці, за місцем проживання і в повсяк- денному житті, її спрямованість визначається самостійно, родиною або соціумом [7].

у 1977 р. Т. Simkins [8] виділив основні системні характеристики формальної та неформальної освіти (табл. 1).

\section{Таблиця 1. Ідеальні моделі формальної та неформальної освіти}

\begin{tabular}{|l|l|l|}
\hline \multirow{2}{*}{$\begin{array}{c}\text { Системні характеристики } \\
\text { навчання }\end{array}$} & \multicolumn{2}{|c|}{ Освіта } \\
\cline { 2 - 3 } & \multicolumn{1}{|c|}{ формальна } & \multicolumn{1}{|c|}{ неформальна } \\
\hline \multirow{4}{*}{ Ціль } & Довготривалі та більш загальні & Короткострокові та специфічні \\
\cline { 2 - 3 } & $\begin{array}{l}\text { Отримання офіційно визнаних документів } \\
\text { про освіту }\end{array}$ & $\begin{array}{l}\text { Отримання офіційно визнаних доку- } \\
\text { ментів про освіту не передбачається }\end{array}$ \\
\hline \multirow{3}{*}{ Зміст } & Тривалий цикл, повний робочий день & Короткий цикл, неповний робочий день \\
\hline & $\begin{array}{l}\text { Стандартизований, орієнтований на основ- } \\
\text { ні положення навчального матеріалу }\end{array}$ & $\begin{array}{l}\text { Індивідуалізований, орієнтований на } \\
\text { результат }\end{array}$ \\
\cline { 2 - 3 } & Академічний & Практичний \\
\cline { 2 - 3 } & Чітко структурований & Гнучкий, особистісно орієнтований \\
\cline { 2 - 3 } & $\begin{array}{l}\text { Вступні вимоги визначають контингент } \\
\text { тих, хто навчається }\end{array}$ & $\begin{array}{l}\text { Особи, які навчаються, визначають } \\
\text { вступні вимоги }\end{array}$ \\
\hline Місце & $\begin{array}{l}\text { Заклади освіти не орієнтуються на близь- } \\
\text { кість розташування від місця проживання }\end{array}$ & $\begin{array}{l}\text { Орієнтовані на близькість від місця про- } \\
\text { живання }\end{array}$ \\
\hline Ресурсозатратність & Ресурсозатратна & Ресурсозберігаюча \\
\hline Контроль & Зовнішній / ієрархічний & Самоврядування / демократичний \\
\hline
\end{tabular}

Неформальна освіта сприятиме більш динамічному та ефективному набуттю нових компетентностей у діяльності медичних сестер, підвищуватиме їхній рівень конкурентоздатності на ринку праці, покращить ефективність надання медичної допомоги.

Висновки. Найпоширенішим видом неформальної освіти для молодших спеціалістів із медичною освітою набуде форма інформальної освіти: участь у фахових нарадах, семінарах, науково-практичних конференціях, симпозіумах, з'іздах, виставках, симуляційних тренінгах, майстер-класах, курсахз оволодіння практичними навичками, стажування у клініках інших країн, дистанційне навчання, у тому числі електронне через фахові інтернет-ресурси.

\section{СПИСОК ЛІТЕРАТУРИ}

1. Про вищу освіту : Закон України // Відомості Верховної Ради. - 2014. - № 37-38.

2. Боренько Я. Освіта для демократичного громадянства та освіта з прав людини: Хартія Ради Європи з освіти для демократичного громадянства і освіти з прав людини та виклики для застосування європейських моделей навчання громадянству та правам людини для України [Електронний ресурс] / Я. Боренько. - Режим доступу : http://www.academia.edu/2053430.

3. Меморандум непрерывного образования Европейского Союза (А Memorandum on Lifelong Learning) [Электронный ресурс]. - Режим доступа : www.znanie.org/docs/ memorandum.html.

4. Освіта протягом життя: світовий досвід і українська практика [Електронний ресурс]. - Режим доступу : http:// www.niss.gov.ua/articles/252.
5. Перспективи впровадження інноваційних форм освіти в Україні [Електронний ресурс]. - Режим доступу : http://www.niss.gov.ua/articles/2665. - Назва з екрана.

6. International Standard Classification of Education ISCED 2011/UNESCO.

7. Айзікова Л. В. Концепція навчання протягом життя у міжнародних документах і дослідженнях / Л. В. Айзікова // Наукові праці [Чорноморського державного університету імені Петра Могили комплексу «КиєвоМогилянська академія»]. - 2012. - Т. 199, Вип. 187. С. 62-64. - (Серія «Педагогіка»).

8. Simkins T. Non-formal education and development. Some critical issues / T. Simkins. - Manchester: Department of Adult and Higher Education, University of Manchester; 1977. - $77 \mathrm{p}$. 